\title{
ウィメンズ・ヘルスの現状と展望
}

\section{International conference of women's health}

\author{
韓国女性健康看護学会 \& 日本助産学会共同主催
}

韓国女性健康看護学会より日本助産学会に学術 交流の依頼があったのは，2002年 6 月のことでし た。本学会としては理事会においてこの申し入れ を受け, 国際委員会を拡大して学術交流の企画・ 運営にあたってきました。

日韓両国の要望を取り入れながら準備を進め, 2003年 7 月 8 日に，18名の韓国女性健康学会員の 方々が来日されました。メンバーの多くは，母性 看護学, 助産学, あるいはウイメンズ・ヘルスに おける教育・研究に携わる大学の教員および大学 院生でした。

一行は成田に到着したその足で矢島助産院へ向 かい, 助産所で行われる自然な分婏の様子や, 女 性たちが集い身体的にも精神的にもケアされる,

\section{日韓学術交流 \\ ウィメンズ・ヘルスの現状と展望}

韓国女性健康看護学会 \& 日本助産学会共同主催

日時 2003 年 7 月 9 日(水) $18: 00 \sim 20: 00$

会場 聖路加看護大学 301教室

\section{【企画・運営】}

日本助産学会国際委員会 加納 尚美 (茨城県立医療大学)

大石 時子（宮崎医科大学）

石川 紀子（愛育病院）

永瀬つや子（茨城県立医療大学）

学術フォーラム担当

堀内 成子（聖路加看護大学）

小陽 美紀（聖路加看護大学）
いわゆる駆け込み寺的な場所としての助産所の活 動を見学してたいへん参考になると話されていま した。また，教材としてぜひ活用したいと出産の VTRを購入され，日本の助産所のような活動を もっと韓国に紹介してほしいとの反応でした。

7 月 9 日は, 聖路加看護大学において, 東京都 中央保健所の方を交え, 日本の子育て支援システ ムについて活発な意見交換が行われました。その 後「ウィメンズ・ヘルスの現状と展望」と題し て, 平日の夕方にもかかわらず 60 名余りの参加者 を得て, 学術フォーラムを開催しました。このフ オーラムでは，4 人のシンポジストによる講演を 通して, 歴史や文化, 社会情勢に裏打ちされた日 韓両国の女性保健をめぐる“今” の実情を知り, 改めてその共通点や相違点を認識した上で, 今後 のウィメンズ・ヘルスのあり方を考えるきっかけ となったように思います。

7 月 10 日には, 横浜女性フォーラムを見学し, 女性学やジェンダー論という視点からの新たな刺 激を得て, 3 日間の日程が終了いたしました。参 加者は,さまざまな交流を通じてたいへん有意義 であったと満足されて帰国されました。

今回の日韓学術交流に協力していただきまし た, 矢島助産院, 東京都中央保健所, 聖路加国際 病院, 横浜女性センターの皆様方にこの場を借り ましてお礼申し上げます。

また，会員の皆様には誌上での情報交流を図っ ていただききたいという願いから，7月9日の学 術フォーラムで使用したシンポジウムやポスター プレゼンテーションの抄録集をお届けいたします。 日本助産学会理事長 堀内成子 


\section{ウィメンズ・ヘルスの現状と展望}

女性の健康問題は, その生殖機能の特異性から生じる問題点をはじめ, 社会におけるジェンダ 一のもつ問題点や, 家族のもつ健康問題など, 複雑多岐にわたります。しかし, それゆえ, 女性 にとって住みやすい社会とは, また, 他のすべての弱者にとっても住みやすい社会であり, 社会 を女性保健の視点から見直すことは有意義なことです。

このたび，日本助産学会では韓国女性健康看護学会から18名の来訪者を迎え，2003年 7 月 8 日 から10日の 3 日間にわたり，ウィメンズ・ヘルスに関する医療保健活動の現状や，将来への展望 を語り合う機会を設けました。

ことに 9 日の18：00から, 聖路加看護大学にて開催される学術フォーラムには, 日韓両国から 4 名のスピーカーを抢迎えし，さらに，ポスタープレゼンテーションも開催いたしました。

女性にとって住みやすい社会づくりは，すべての人びとにとっての住みやすい社会であるとの 認識をもち，国境を越えた共有財産としての「女性中心のへルスケアの創造」を求めたいと心か ら願います。

日本助産学会理事長 堀内 成子

\section{プログラム}

*開会挨拶

韓国女性健康学会 Park Young Sook

*Part 1：シンポジウム 司会 石川紀子（愛育病院）

- Women's health status issues in Korea Kim Jeung Im

- Reproductive health/rights for Korean and Japanese women 大石 時子

- The trends of nursing research on women's health in Korea

・自然なお産・育児支援から女性への暴力防止を目指して Park Young Sook, Lee Sook Hee *Part 2：ポスタープレゼンテーション

1 Relation on health perception, health behavior and health status

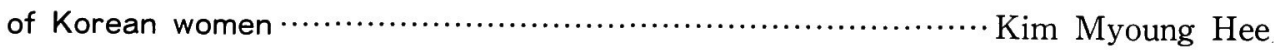

2 A survey on the adult women's depression Kim Soon Ae, Kim Gyung Hee

3 Effect of women's health promotion program on interpersonal relationship and quality of life

. Kim Myung Hee, Kim Soon Ae, Kim Gyung Hee, Lee Nam Hee

4 Effect of Qi-therapy on premenstrual syndrome Jang Hye Sook Lee Myeong Soo, Lee Myung Suk, Park Rae kil, Moon Sun Rock

5 Menarche experience of the Korean nursing college student

6 Effect of postpartum care program for primiparous women and care-givers on the knowledge and behavior of postpartum care and postpartum recovery in primiparous women

- Park Mi Kyung, Lee Young Sook

7 The effect of a pain reducing program for women with low back 


\title{
Women's health status issues in Korea
}

\author{
Kim Jeung Im, RN., $\mathrm{PhD}$
}

Soonchunhyang University
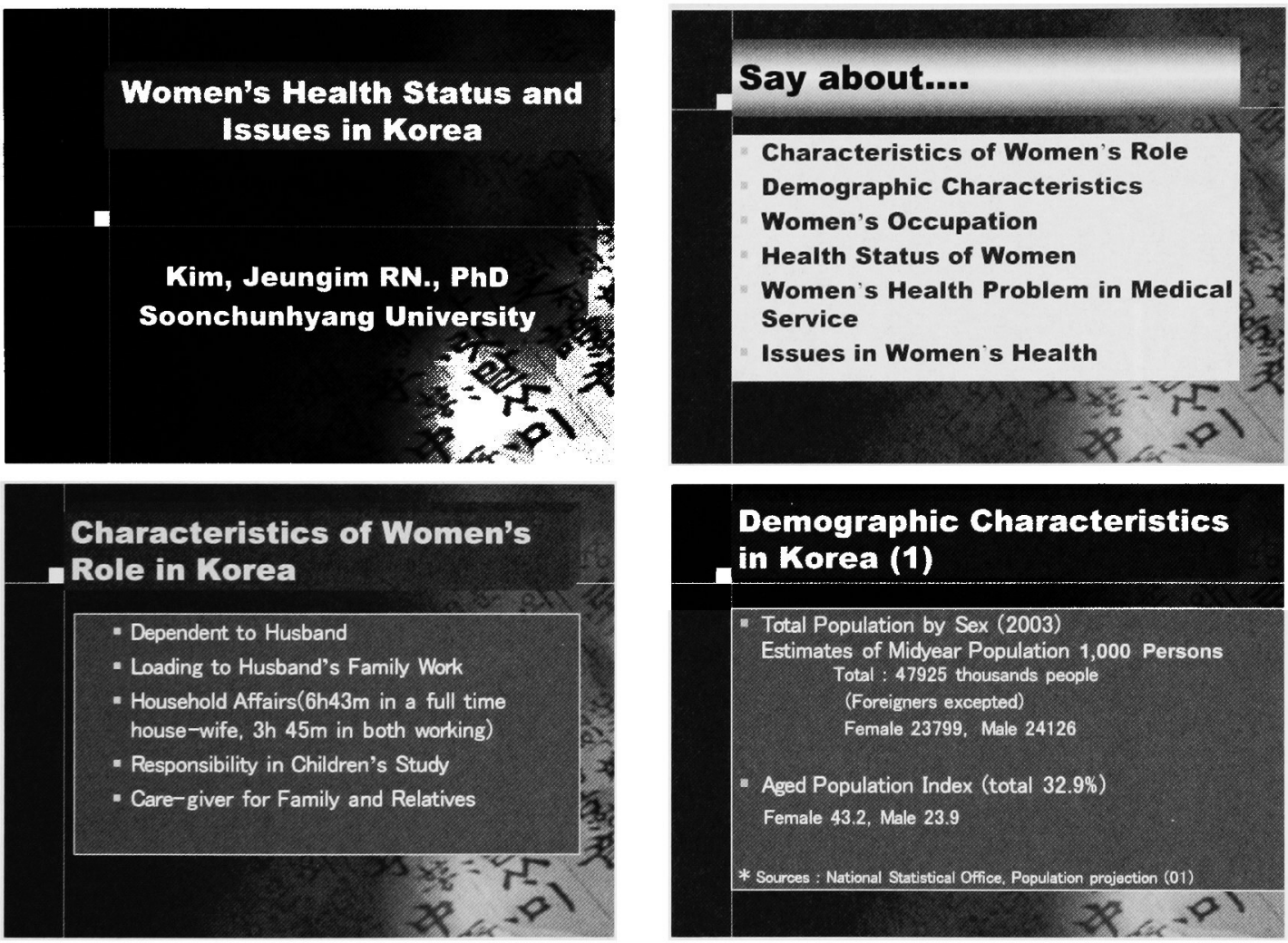

\section{Demographic Characteristics} in Korea (2)

- Prolonged Life Expectancy

First Marriage age

Man:29.8, Woman: 27.0 (2003)

Average life man: 72.3 , woman 79.7

- Increasing in Divorce Rate

- 42.2\% (Divorce No/Marriage No)

- Crude Divorce Rate:

2.8 per 1000 person (2001)

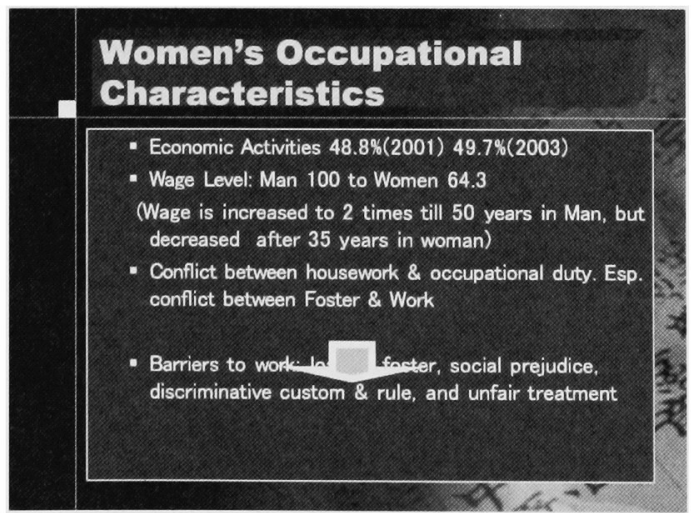


Health Status of Women in Korea (1)

- Total fertility rate: $2.7(1980) \quad 1.6(1990)$ $1.47(00) 1.3(03)$

- Age-specific Fertility Rate per 1000 persons (01)

\begin{tabular}{l}
\begin{tabular}{|l|l|l|l|l|l|l|}
\hline $15-19$ & $20-24$ & $25-29$ & $30-34$ & $35-39$ & $40-44$ & $45-49$ \\
\hline 2.2 & 31.6 & 130. & 78.3 & 17.2 & 2.5 & 0.2 \\
\hline
\end{tabular} \\
- Crude Birth Rate: $13.4(00)$ \\
\hline
\end{tabular}

* Source: KNSO, Annual Report on the Vital Statistics (02)

Artificial Abortion Rate

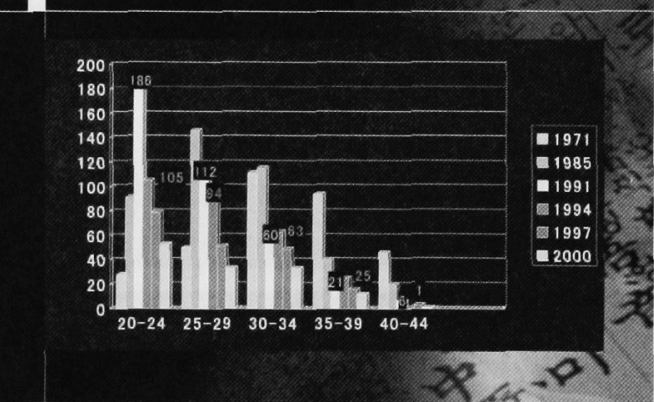

Health Status of Women in Korea (4)

- Low in Breast Feeding Rate10.2\% (2000)

- Mixed feeding 52.5\%(1997) $\rightarrow .65 \%(2000)$

- Death Cause (2001)

- Ca(1), CVA(2), Heart Dz(3), DM(4)

- $50.4 \%$ of Total Death Cause

- Cancer in Women

- increasing in Bereast Ca 15.18 (2000)

- Stomach(15.8\%), Breast(15.1\%), Cx Ca(10.6\%)

Ovary $(4.1 \%)$, Endometrium $\mathrm{Ca}(1.8 \%)$

- Never done for their health $(49.4 \%)$

Issues in Women's Health in Korea

- Self-help Group in Life with Disease Breast Cancer Hysterectomy(needed)

- Women's Health Care center-

Movement toward Women's Health

Education and Counseling Program Development and Management

Pamphlet, Web site applicable

- Women's Health Practitioner: informal

- Women's Health Care Service: based local clinic. post-partum care station
Health Status of Women in - Korea (2)

- Artificial Abortion Rate /1000 persons(2000). 20-44 years: $39 \%$, average 0.7 times

\section{Korea (3)}

Heaith Status of Women in
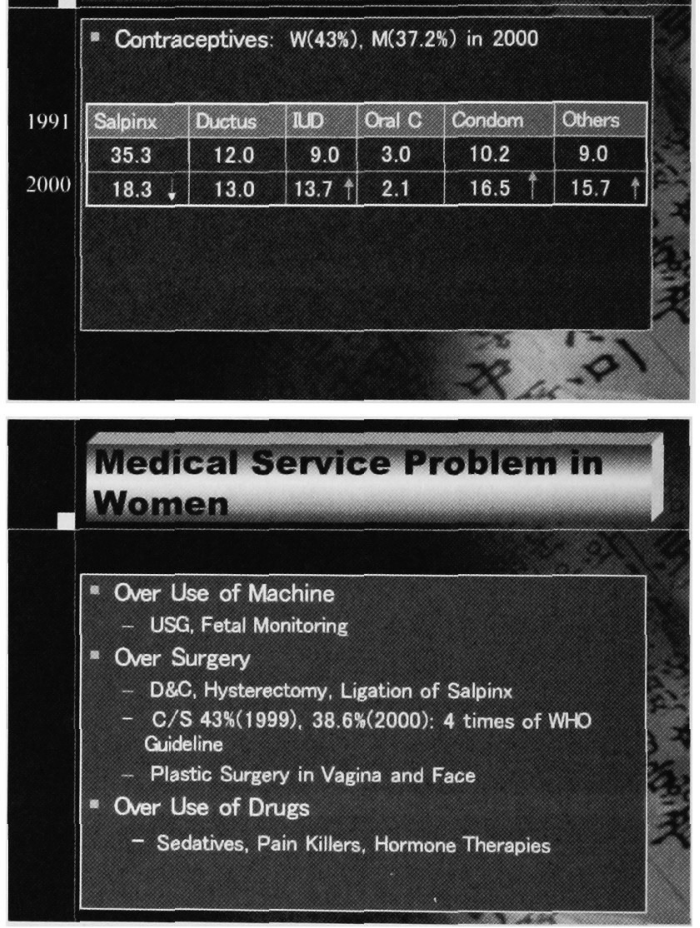


\title{
Reproductive health/rights for Korean and Japanese women
}

\author{
大 石 時子 \\ 宮崎医科大学
}

Reproductive Health/ Rights for

Korean and Japanese Women

Tokiko Oishi, RN, CNM, MPH

Miyazaki Medical College

\section{徒軍慰安婦·Sexual Slaves}

第2次大戦中、日本軍の $\quad$ STD

管理下におかれ、無権利状・不妊

態のまま一定の期間拘束さ ・PTSD

れ、将兵の性交の相手をさ ・自殺

せられた女性たち社会的刵尉

（吉見羲昭,岩波新書, 1995) - Low self-esteem

Korea, Taiwan, China ・結婚できない

Indonesia, Philippines 離婚
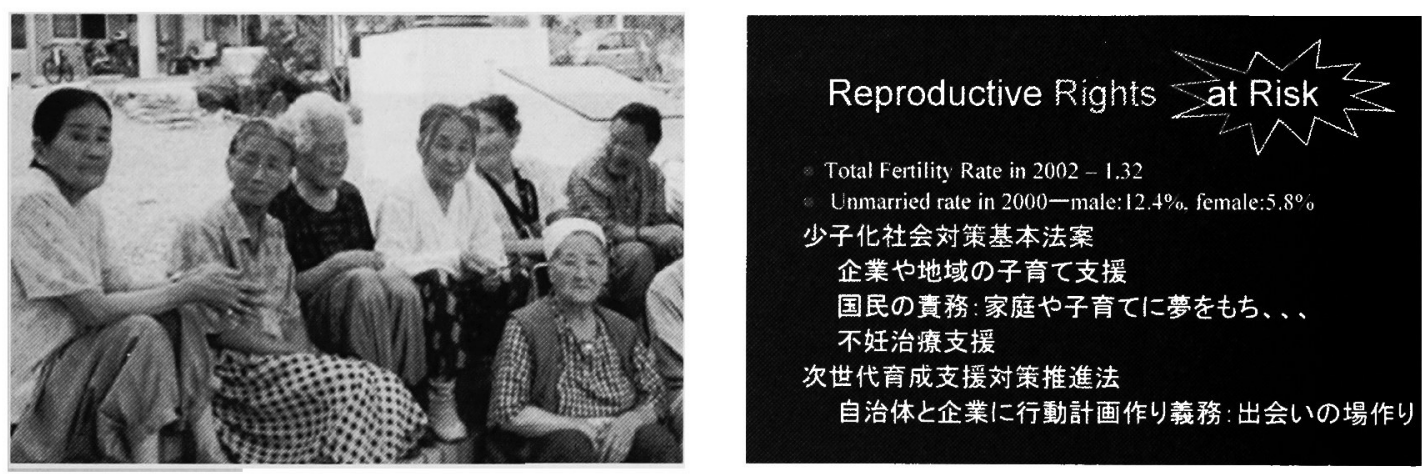

Program of Action, UN, Cairo, 1994

,..reproductive rights embraces certain human rights

........the basic right of all couples and individuals

to decide freely and responsibility

the number.spacing and timing of their children....

,...the right to all to make decisions concerning reproduction free of discrimination. coercion and violence,

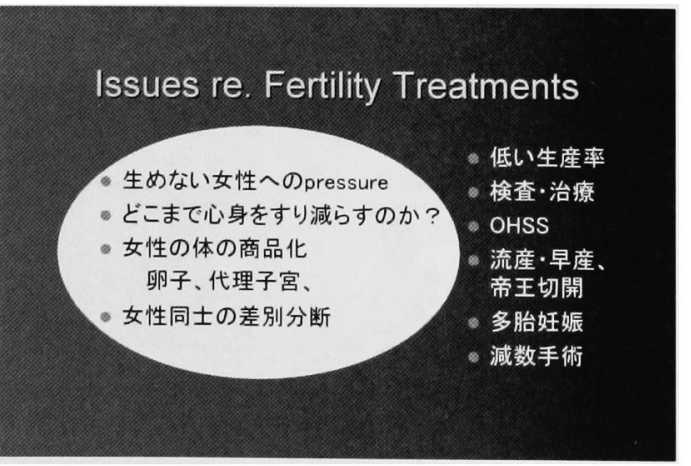


Issues re. Preimplantation

Genetic Diagnosis

。遗伝珐断

胚の取捨選択

Designer's baby

- 性差別

- 優生思想

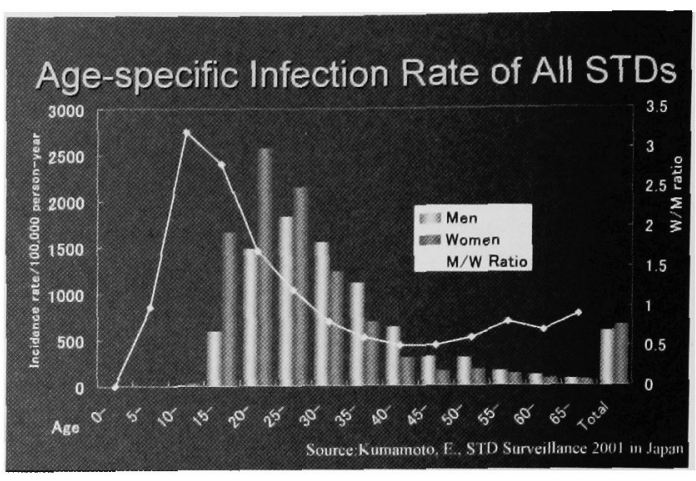

Age-specific Heterosexually Transmitted HIV Cases in comparison between Men \& Women by 2001
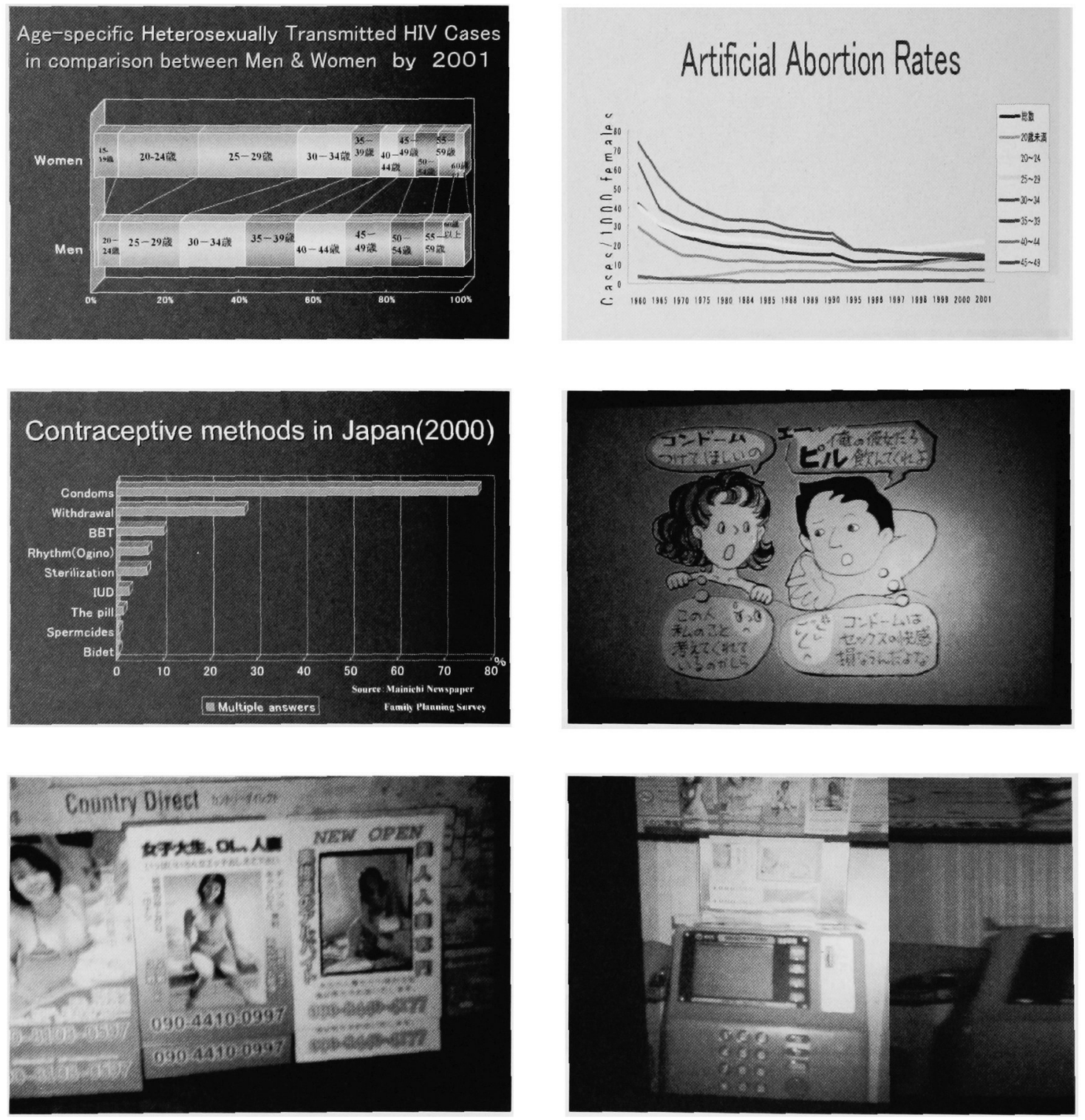


\section{Status of Domestic Violence}

命の危険を感じるくらいの暴行をうけたことがあるー4.6\%

医師の治瘵が必要となる程度の暴行一 $4.0 \%$

秎地捬

いやがっているのに性的な行為を強要されたー $17.7 \%$

、配偶者暴力相談支援センターへ:

35943件 (2002)

保護命令発令: 1571 件 (2002)
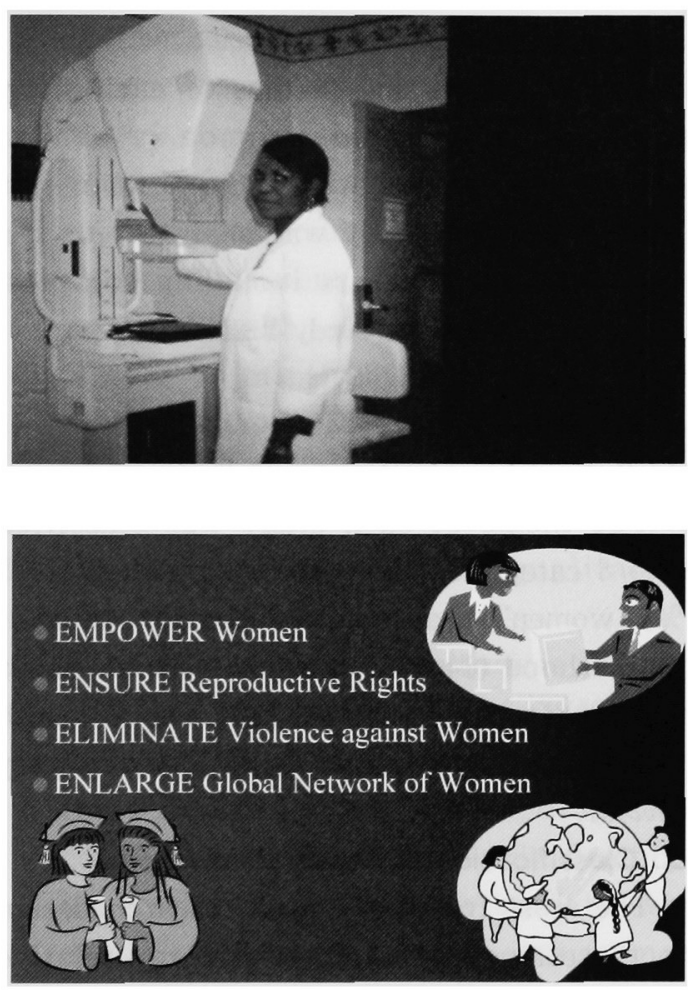
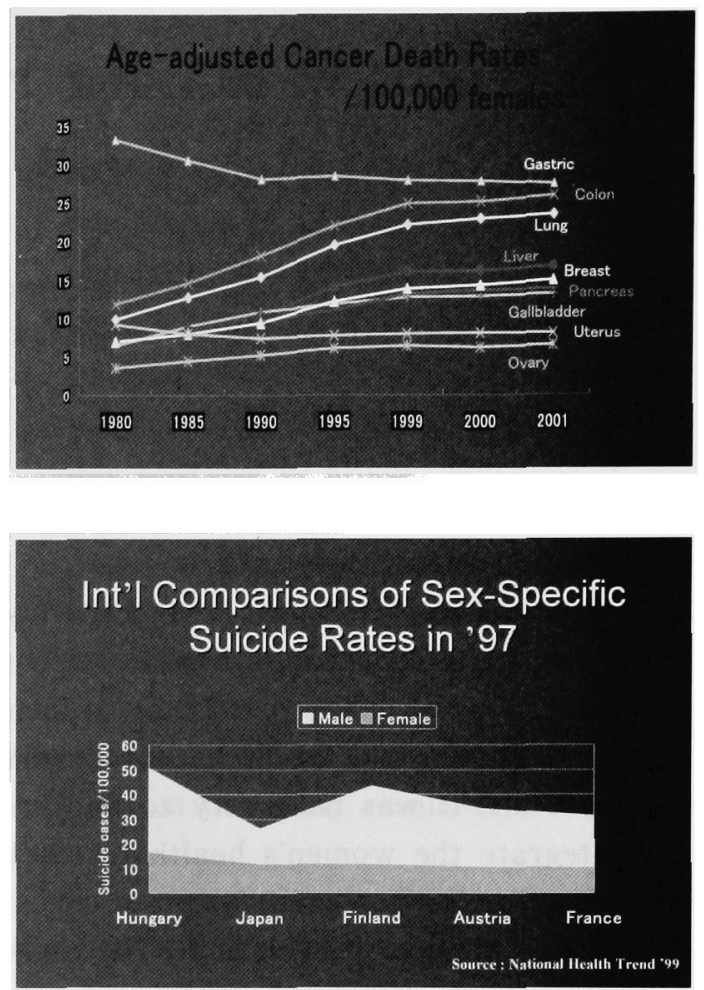

Int'I Comparisons of Sex-Specific Suicide Rates in ' 97

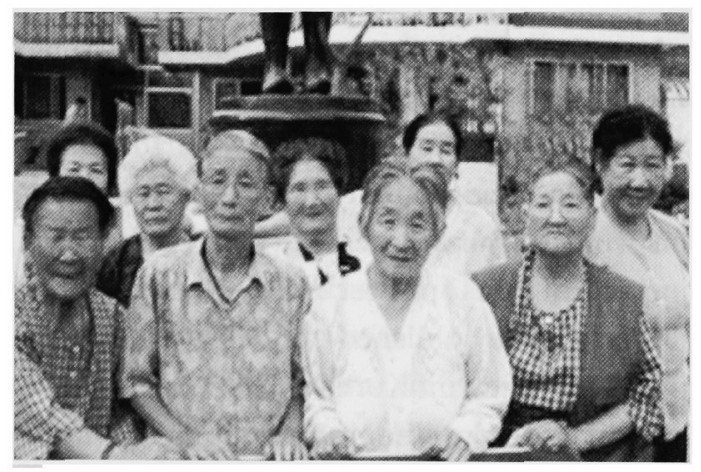




\title{
The trends of nursing research on women's health in Korea
}

\author{
Park Young Sook, PhD, RN \\ College of Nursing, Seoul National University \\ Lee Sook Hee, PhD, RN \\ Seogang Jungbo College
}

\section{Significance of the study}

Health concepts in Women have been classified depending on scholars by the various perspectives, which make it difficult to identify the definition and the areas of women's health. Thus, it was necessary to analyze and integrate the women's health research studied up to the present to improve understanding of women's health and to accumulate scientific knowledge from the valuable findings.

\section{Purpose}

The purpose of the study was to analyze the topics and contents of research studies on women's health nursing by; (1) identifying journal articles, master's theses, and doctoral dissertations published for 10 years in nursing discipline in Korea; (2) analyzing and classifying the themes, designs, samples, methods, as well as results of those studies; and (3) providing future direction for women's health studies.

\section{Methods}

A total of 390 women's health studies were selected for the analysis, which accounted for $12.7 \%$ of the total of 3,080 nursing papers published from 1988 through 1997 in Korea. Those were 158 studies out of 1,010 articles from 9 Korean nursing journals, and 232 theses and dissertations out of 2,070 data sets published during that period of time.

Main concepts and themes of each study were listed first, and common or similar concepts were categorized into 8 main subjects. Then each study was analyzed for frequencies and contents including samples, methods, as well as study results.

\section{Results}

\section{Categories of the research themes}

The theme of each study was classified into 8 categories; those were childbirth $(19.5$ $\%)$, women's health status/behavior (18.5\%), motherhood (14.9\%), cultural/social issues $(12.8 \%)$, menstruation $(8.7 \%)$, mental health $(8.2 \%)$, caring activities $(8.2 \%)$, and surgery $(7.7 \%)$.

\section{Classification of research methods}

The most frequently used research design in those studies was descriptive or relative study $(70.8 \%)$, and the rest of them utilized either experimental (14.4\%) or qualitative research design (14.1\%).

\section{Analysis of contents}

(1) Childbirth was the most frequently inquired topic in women's health area, which accounted for $21 \%$ of the total studies. Topics were classified further into subcategories of pregnancy $(n=36)$, delivery experiences $(n=19)$, postpartum $(\mathrm{n}=14)$, infertility $(\mathrm{n}=6)$, and abortion issues $(n=7)$. 
(2) Regarding women's health status $(n=13)$ and health behaviors $(n=59)$, studies were done in diverse populations such as, teens, elderly women, and women in low-income class, etc. Pender's framework was used in 15 studies for explaining women's health behaviors.

(3) The theme of motherhood was clustered into three sub-subjects, which were maternal role, mother-child relationship, and breastfeeding mostly utilizing descriptive or relative designs.

(4) Socio-cultural issues were increasing in studies for 10 years, and topics were found to be various, containing sexuality related issues, substance abuse, sexual abuse/harassment, AIDS, cosmetic surgery and health, and smoking, etc.

(5) Studies on menstruation included topics of menarche, PMS, as well as menopause and climacteric symptoms. One fourth of them were found to utilize experimental designs or qualitative research methods.

(6) The issue of mental health was divided into two parts; the topic of stress was mainly studied in housewives, and the topic of mental health including selfconcept, sexual identity, family functioning, body image, or state anxiety was dealt in adolescent and young women population.

(7) Caring experiences were explored mostly in women who took care of their child- ren, which exploring women's health issues of stress, burden, family functioning, and depression in their lives.

(8) Studies on surgery were done in women who experienced hysterectomies and mastectomies, incorporating fairly diverse health issues such as, partner support, sexuality, effects of music therapy/alternative therapy, adaptation process, rhythmic exercise to stress management, etc. Fifty percent of the studies performed experimental or qualitative designs, which was relatively high proportion compared to other topics of studies.

\section{Conclusion}

Based on the study result, it is suggested that;

1) Future study needs to aim to integrate the results of the previous research to provide evidence-based nursing practices in women's health fields. 2) Concept analyses are also required for clear defining and operation of nursing concepts; 3) Instrument development assuring proper reliability and validity would improve the quality of scientific findings; 4) It is recommended to study on topics of the effects of socio-cultural environmental on women's health or study on developing programs for women's health promotion; 5) Finally, studies are needed to explore women's experiences in current health care systems, which could be reflected in establishment of future health policy. 


\section{自然なお産・育児支援から女性への暴力防止を目指して}

\section{まつしま病院の取り組み}

\section{○医療の中の封建制の壁をなくす}

個人の生き方を尊重した医療を実践するために は，これまでの権威的な医療ではなく，対等な関 係づくりと個人の意見を医療サービスに反映でき る環境づくりを心がけています。

・医療従事者と利用者との関係

・職員間の関係

\section{○自然なお産／からだにやさしいお産}

お産は生理的現象です。ですから不必要な医療 介入をせず，本来女性に備わっている自然の力を 発揮できるようなサポートを心がけています。

・主体性の尊重

・お産する女性が自己管理できるような支援

・助産師主体の助産・産褯支援

\section{○育児支援}

孤立感や不安感を抱えながら子育てをしている 親たちは少なくありません。

自分の悩みを対象化し，自信と余裕をもって子 育てができるよう支援しています。

-母乳外来

- 助産師外来

・電話訪問

・親と子のサロン

・託児サービス

- 1 か月健診時の相談

・カウンセリング

\section{○女性や子どもへの暴力防止・対応}

暴力は女性の健康や子どもの発達に深刻なダメ ージを与えます。

女性と子どもが安全に健康に生きていけるよう な社会的活動や啓蒙を行っています。

- 性暴力被害対応

・ドメスティック・バイオレンスや子どもへの 虐待防止・対応

・カウンセリング

・他機関との連携

\section{○職員教育}

目的

(1)医療の本来の姿について考える機会をもつ。

(2)社会のしくみや，そこに起こっている問題を女 性の視点で捉え直す。

(3)自分の価值観を知ることと, 多様な価值観につ いて理解する。

(4)まつしま病院が目指す医療について理解する。

質の良い医療サービスを提供できるよう職員の 意識を高める努力をしています。

・職員研修

・リーダー研修

- 新入職員研修

・院外研修 


\title{
Relation on health perception, health behavior and health status of Korean women
}

\author{
Kim Myoung Hee \\ Department of Nursing, Semyung University
}

\section{Introduction}

Often health care for women has focused on the reproductive system to the exclusion of other health needs. The lack of research focuses on women's unique and common health issues would be major problem to enhanced optimal level of women's health. Health care providers have to recognize biological and social differences between women and men.

A variety of health related literature posits a relationship of various personal emotions, attitudes and behavior to health status. Current literature supports the idea that maladaptive psychosocial responses conductive to producing discomfort, dysfunction or illness can be altered to promote health (Pender, 1987).

As relationships among variables and health status are delineated, nursing intervention for women's health can be based on scientific evidence.

Three specific study questions were to identify:

1. The level of health perception, health behavior, and health status of Korean women.

2. The relationship of socio-demographic variables to health perception, health behavior, and health status of Korean women.

3. The correlations among the three study variables: health perception, health behavior, and health status.

\section{Methods}

The design was a descriptive relative study. A convenient sampling method was used for collecting data from 103 Korean women, over 18 years of age, during the period from Sept. 1 to Nov. 30, 2001. The study's subjects were interviewed using a structured questionnaire.

The instruments for this study were the health perception scale developed by Ware (1977), the health behavior scale by Ko, Kumja (1987). Health status was measured by the short form Cornell Medical Index (CMI) modified by Nam, Hochang (1965).

The data were analyzed SPSS $\mathrm{PC}^{+}$, by frequency, mean, t-test, ANOVA, and Pearson correlation coefficients. Also, Duncan test was utilized for post hoc test of ANOVA.

\section{Results}

The results of this study are as follows;

1. The mean score for health perception was $3.02(\mathrm{~S} . \mathrm{D}=0.39)$ on a 5 point scale.

2. The mean score for health behavior was $3.08(\mathrm{~S} . \mathrm{D}=0.43)$ on a 5 point scale.

3 . The mean score for health status was 18.54 on 58 items. The mean score for physical symptom of a subscale of health status was 11.30 on 36 items and the 
mean score for psychological symptom was 7.37 on 22 items.

4. The relationship of socio-demographic variables to health perception, health behavior, and health status of Korean women:

1) There were significant differences in the scores of health perception by disease experience $(t=-3.37, p=0.00)$ and perceived health status $(F=31.16, p=0.00)$.

2) There were significant differences in the scores of health behavior by age $(F=4.59$, $\mathrm{p}=0.01)$, marital status $(\mathrm{t}=-5.56, \mathrm{p}=$ $0.00)$, educational background $(t=2.90$, $\mathrm{p}=0.00)$, and drinking or not $(\mathrm{t}=2.17$, $\mathrm{p}=0.03)$.

3) There were significant differences in the scores of health status by educational background ( $t=2.28, p=0.02)$ and disease experience $(t=2.61, p=0.01)$, and perceived health status $(\mathrm{F}=13.44, \mathrm{p}=$ $0.00)$.

5. Health perception showed significant positive correlation with health behavior $(r=$ $0.39, \mathrm{p}=0.00)$.

Health perception showed significant negative correlation with health status $(r=-0.44$, $\mathrm{p}=0.00$ ), that is, the more women perceived about health, the less she complained unhealthy symptoms. Health behavior had no significant correlation with health status but showed a positive correlation with psychological symptom of a subscale of health status $(r=-0.19$, $\mathrm{p}=0.05)$.

\section{Conclusions}

Many of the leading causes of disease are preventable, through changes in health perception and behavior. The need to increase individual awareness of relationships among health perception, health behavior, and health status and to enhance knowledge regarding the long-term effect of positive health behavior, is an important nursing strategy for women's health promotion.

Finally, this result will provide basic data for health status and behavior of Korean women, and provide important variables for the development of a nursing intervention program for health promotion in Korean women.

Keywords : Health perception; Health behavior; Health status.

\title{
A survey on the adult women's depression
}

\author{
Kim Soon Ae, Kim Gyung Hee \\ Seoul Women's College of Nursing
}

\section{Purpose of Research}

On a weak woman coping with health management, she was not managed adequate intervention even though depression is a serious disease to happen the various changing symptoms.
So this research is confirmation of exposure of depression in woman population, development of the therapeutic group program for depression prevention and application of basic survey. 


\section{Method}

The data was collected during 22 nd August to 30 th September 2002. The subjects of this research were 468 adult women being on an area in Korea. The tool of this research was used CES-D which is widely used for testing normal person depression.

The data were analyzed by SPSS PC Win 8.0 version and analyzed with frequency, percentage, t-teat, ANOVA, $\chi^{2}$-test, and Duncan's multiple comparisons.

\section{The results were as follows}

1. Potential depression (above 23 score) was $24.1 \%$, mild depression was $33.1 \%$ and normal state was $42.7 \%$.
2. On comparing with statistically characteristics, there were significant differences according to the case of being mentally ill patient as a family member $(p=.000)$ and frequency in contact with mentally ill patient $(\mathrm{p}=.000)$.

3. By age Group, group of ' 20 ' and 'above 60 ' have high possibility of being depression.

\section{Conclusion}

The women caring mentally ill patients as living with them in the family are first of all needed the intervention for depression

Key words : Women, Depression

\title{
Effect of women's health promotion program on interpersonal relationship and quality of life
}

\author{
Kim Myung Hee, Kim Soon Ae, Kim Gyung Hee, Lee Nam Hee \\ Seoul Women's College of Nursing
}

\section{Purpose of research}

The Purpose of research is for developing the quality of women's life by early detection, prevention and caring as applying the intensively effectual program for less cared women's health problems in the issues of health promotion project.

So this research is purposed to look out the effectiveness of application of Women $s$ Health Promotion Program.

\section{Method}

This research is comparing with before and after result of program for measuring the effectiveness of health promotion program on one-group in a pre-and-post design as quasi-experimental design.
The subjects were 17 middle-aged women (over 40 ages) who understood the purpose of this research throughout a village office, brochure and communal committee and continuous participant of the program.

The tools of research were used Relationship Scale of Schein \& Guerey (1980) and Dunbar's Quality of Life Scale of Korean version.

Period of research was from 15th May to 12 th June in 2002.

The data were analyzed by SPSS PC Win 8.0 version and analyzed with frequency, percentage, t-test, ANOVA, $\chi^{2}$-test, Duncan's multiple comparisons. 


\section{Results}

According to the statistically characteristics, the area of interpersonal relationship $(\mathrm{p}=.001)$ showed significant difference by continuance exercise.

In interpersonal relationship change scalebefore applying Women s Health Promotion Program, the result was 85.14 score but the after was 93.29 score-the program has helped increasing the point.

Also there were significant differences in the area of a lower domain of openness ( $p=$ $.002)$ and comprehension $(p=.002)$ at interpersonal relationship of change scale. But it is not statistically significant difference on quality of life scale on programming of before and after.

There was positive correlation on interpersonal relationship change scale and quality of life scale $(r=0.07)$ of before and after Women s Health Promotion Program

\section{Conclusion}

Application of women health program, there will be a great on the women $s$ health promotion and efficiency of medical cost.

As the research is the limit to confirmation of the effectiveness of short-term application, the program is in need of after care.

Key words : Women's Health Promotion, Interpersonal Relationship, QOL

\title{
Effect of Qi-therapy on premenstrual syndrome
}

\author{
Jang Hye Sook \\ 1Department of Nursing, Wonkwang Health Science College \\ Lee Myeong Soo \\ Professional Graduate School of Oriental Medicine, Wonkwang University \\ Center for Integrative Medicine, Institute of Medical Science, Wonkwang University \\ Lee Myung Suk \\ Department of Nursing, Mokpo Catholic University \\ Park Rae Kil \\ Professional Graduate School of Oriental Medicine, Wonkwang University \\ Moon Sun Rock \\ Center for Integrative Medicine, Institute of Medical Science, Wonkwang University \\ Department of Radiation Oncology, Wonkwang University
}

\section{Objective}

Qi-therapy is an oriental complementary therapy preventing, curing disease and strengthens health and improving the human potentiality through regulation of body. Retrospective community survey estimate $79.4 \%$ of women have suffered from symptoms and $97.7 \%$ experienced at least one premenstrual symptom in Korea. This study assessed the effects of Qi-therapy (QT) on premenstrual symptoms in women with premenstrual syndrome (PMS).

\section{Materials and methods}

Forty-six college women were randomly allocated to receive QT (20.91 years old, 
$\mathrm{n}=23$ ) or control (21.77 years old, $\mathrm{n}=22$ ).

The experimental group receives QT for 9 times during 3rd and 4th cycle with completing the PMS diary, and control group complete only the diary. We also measured pain, depression and anxiety level with visual analogue scale (VAS) to explore participants' response to Qi therapy.

\section{Results}

Total PMS scores were significantly lower at postmenses than premenses $(\mathrm{p}=0.0001)$. Significant differences were found between premenses and postmenses scores in all five categories: negative feeling $(\mathrm{p}=0.002)$, pain $(p=0.0001)$, autonomic reactions $(p=0.0002)$, water retention $(p=0.0001)$, behavioral change $(p=0.002)$. In the category of pain, the difference of premenses and postmenses was significantly higher in the control group compared with QT group $(\mathrm{p}=0.036)$. There were more remarkable reductions on pain, depression and anxiety in the experimental group than in the control group: pain $(\mathrm{p}=$ $0.001)$; depression $(\mathrm{p}=0.0001)$; anxiety $(\mathrm{p}=$ $0.0005)$.

\section{Conclusion}

This tudy showed that Qi-therapy reduces the level of pain, depression, anxiety, and symptoms of PMS. Hence it may be useful to develop Qi-therapy programs as a nursing intervention for PMS.

\title{
Menarche experience of the Korean nursing college student
}

\author{
Oh Yoon Hee \\ Doctoral Degree student, RN, College of Nursing, Seoul National University \\ Park Young Sook \\ Professor, Ph.D., RN, College of Nursing, Seoul National University
}

\section{Purpose}

This study has been conducted to find the meaning of a menarche to the Korean nursing college students and to understand their attitudes toward an menstruation.

\section{Method}

The method used in this study was the hermeneutic phenomenological approach. The study followed the Four Steps by van Manen's methodology. Specially, the data collection for this study has been done by in depth face to the face interview, analysis of Korean nursing students' writings. The in- depth interviews have been done with twenty nursing college students lived in Kangwon Province. The data were gathered from March 3 to May 25, 2002.

\section{Results}

Although the experience and attitude of the menarche of the Korean Nursing college student was different from each other, it is possible to summarize as following 6 major attributes of the experience and attitude of the menarche of the Korean Nursing college students.

'Embarrassment by the menarche', 'Shame- 
ful and Uneasy feeling caused by the menarche', 'Keep dumb-There is no shock or fear', 'Delight-I'm now be a woman', 'Natural process of growth', Findings of this study made possible to be deeply understanding of the Korean Nursing college students' experience on menarche.

\section{Conclusion}

The objective of the study was to understand the experience and attitudes toward the menarche of the Korean Nursing college students. Their attitudes to the menarche were divided to positive and negative attributes. To improve the positive experience of the menarche, it may help to give them a sex education in adequate period of young girl. It is suggested that Further research is required to the effect of the sex education of the young girl.

Key word: menarche experience

\title{
Effects of postpartum care program for primiparous women and care-givers on the knowledge and behavior of postpartum care and postpartum recovery in primiparous women
}

\author{
Park Mi Kyung \\ Chunnam Techno College \\ Lee Young Sook \\ Chonnam National University
}

This study was conducted to develop an effective postpartum care program for women delivered of their first babies and care-givers and to evaluate the effects of the program on postpartum care knowledge, postpartum care behavior and postpartum recovery in primiparous women. For this control group quasi-experimental study, the primiparous women who had normal delivery at OBGY clinics in Gwangju-city and then were supposed to care for with the assistance of their mothers at their homes were participated from April 26 to August 27,2002 . The participants were assigned to an intervention group of 32 mothers and a control group of 32 mothers.

The degrees of postpartum care knowl- edge, postpartum care performance, postpartum functional status, physical discomfort and perceived health status were measured in both groups before the intervention. The participants who attended intervention group took a six-hour postpartum education during their hospital stay and performed a fourweek postpartum care at their homes. The education program included general hygiene support, breast care, good nutrition, rest and postpartum exercise. As part of posttest, the variables were compared two times with pretest and provided postpartum attendance instrument at 4 weeks after intervention, and with the instruments of postpartum functional status and physical discomfort at 6 weeks after intervention. 
Data were analyzed with SPSS/win 10.0 $\mathrm{PC}^{+} \cdot \chi^{2}$-test, Fisher's exact probability and $\mathrm{t}$-test were used to test the homogeneity of two groups. Hypothesis to identify the effects of postpartum care program were tested with t-test, Wilcoxon rank sum test and ANOVA.

The results showed that all hypotheses were supported statistically with significant differences between two groups.

The degree of knowledge about postpartum care in mothers who participated in postpartum care program was significantly higher than those who didn't participate in the program $(t=5.544, p=.000)$.

The degree of postpartum care behavior, including the degrees of postpartum performance and provided postpartum attendance, in intervention group was significantly higher than control group $(t=3.743 / t=3.95$, $\mathrm{p}=.000)$.

Also, the level of postpartum recovery, which included postpartum functional status, physical discomfort and perceived health state, in mothers of intervention group was significantly higher than those of control group. They performed well with minimal functional activity $(\mathrm{F}=4.365, \mathrm{p}=.042)$ and felt less physical discomfort $(F=7.497$, $\mathrm{p}=.008)$, and perceived better health status $(Z=2.942, p=.003)$.

The above findings showed that mothers delivered of their first babies gained increased knowledge about postpartum care and performed postpartum care in a very skillful way, and were well cared for from care-givers after their participation in the postpartum care program. As a result, the mothers felt less physical discomfort and were in a better state of health.

Therefore, this program needs to be applied as a new nursing intervention because this postpartum care program was proved useful for an effective postpartum care.

Key words : Primiparous women, Postpartum care-givers, Postpartum care knowledge, Postpartum care behavior, Postpartum recovery

\title{
The effect of a pain reducing program for women with low back pain during pregnancy
}

\author{
Oh Hyun Ei \\ Professor, Ph.D., RN, Department of Nursing, Chosun University \\ Lee Young Sook \\ Professor, Ph.D., RN, Department of Nursing, Chonnam National University
}

\section{Purpose}

This research studies the effects of a pain reducing program for women with back pain during pregnancy with regards to postpartum pain intensity, flexibility, postpartum functional status, and postpartum depression.
Method: The research design was a quasiexperiment designed with non-equivalent control group pre and post-test. The research lasted form May 18 to October 7, 2002. The sample of 52 pregnant women between 36 and 39 weeks gestation were selected in 
order of arrival from each hospital. Research began in step 1 with pain drawings, visual analogue scale (VAS) for pain, posterior pelvic pain test, functional limitation, and flexibility. Step 2 of the research began 10 days after childbirth measuring functional status and postpartum depression. Data were analyzed with chi-square test, Fisher $\gamma \mathrm{s}$ exact probability and t-test using SPSS/Win $10.0 \mathrm{PC}^{+}$

\section{Result}

Hypothesis 1. Back pain will be reduced for pregnant women who participate in the pack pain relief program as compared to pregnant women who do not.

Hypothesis 1-1. The experimental group will have lower pain intensity than the control group. This was supported ( 8 weeks after birth, $\mathrm{t}=-2.019, \mathrm{p}=0.040)$.

Hypothesis 1-2. The experimental group will have less function restriction intensity then the control group. This was supported ( 8 weeks after birth $\mathrm{t}=-2.318, \mathrm{p}=0.026$ )

Hypothesis 2. There will be a difference in flexibility between pregnant women who participated in the back pain relief program and pregnant women who did not. This was not supported.

Hypothesis 3. Pregnant women who participated in the back pain relief program would have a higher postpartum functional status level than women who did not. This was not supported.

Hypothesis 4. Pregnant women who participated in the back pain relief program would have a lower level of postpartum depression. This was not supported.

\section{Conclusion}

This research looked into back pain late in pregnancy and the effects of a pain reducing program postpartum. With research support of lower pain intensity and less functional restriction intensity, nurses should take the responsibility to check pain intensity during pregnancy, inform pregnant women of pain management, and inform women of a postpartum pain reducing program for the health of the body and the mind.

Key words: Postpartum, Low back pain, Low back pain Reducing Program 